\title{
Kendala masyarakat dalam mengembangkan objek wisata Embung Sungai Nanam di jorong aie sanam kecamatan lembah gumanti kabupaten solok
}

\author{
Enika Febria $^{1)}$, Rinel Fitlayeni' ${ }^{2}$, Hefni ${ }^{3)}$ \\ Program Studi Pendidikan Sosiologi STKIP PGRI SUMBAR \\ Email: Enikaferia@gmail.com rin3l
}

\begin{abstract}
Abstrak
Jorong Aie Sanammerupakan jorong yang terletak di Na gari Sungai NanamKeca matan Lembah Gumanti Kabupaten Solok. Jorong a ie sanam memiliki pemandangan yang indah dan letaknya yang sta rategis yang dikelilingi perbukitan. Potensi wisa ta yang ada di jorongan Aie Sanam berupa Embung Sungai Nanamdan Bukik Cambai.Embung Sungai Nanam berdiri sejak tahun 2017, yang dibangun oleh PUPR yang kemudian dalam pengelolaannya diserahkan kepada masyarakat Aie Sa nam. Da lam pengelolaannya ini ma syarakat menjadikan Embung sebagai objek wisa ta. Namu dalam pengelolaannya, sejauh ini wisata tersebut belum begitu optimal. Penelitia n ini bertujuan untuk mendeskripsikan kendala yang dialami masyarakat dalam mengembangkan Objek Wisata Embung Sungai NanamDi Aie Sanam Di Kecematan Lembah Gumanti Kabupaten Solok. Penelitian ini menggunakan teori fungsionalisme struktural dari paradigma fakta sosial mengenai disfungsional yang dikemukakan oleh Robert K. Merton. Penelitian ini termasuk jenis penelitian deskriptif dengan pendekatan kualitatif. Pemilihan informan menggunakan purposive sampling dengan jumlah informan 9 orang, jenis data yang digunakan dalam penelitia n ini yaitu data primer dan sekunder. Metode pengunpulan data yang digunakan yaitu observasi non partisipan dan wawancara mendalam, unit a nalisis data yang digunakan yaitu kelompok. Teknik analisis data yang digunakan adalah model Miles dan Huberman, Hasil dari penelitian menunjukkan ba hwa yang menjadi kendala masyarakat dalam mengembangakan wisa ta Embung Sungai Nanam dijorong Aie Sa nam diakibatkan oleh 1) keterbatasan dana dan penyelewengan dana, 2) kurangnya kerjasama masyarakat yang diakibatkan karena sensitifitas masyarakat, serta adanya pro dan kontra masyarakat terhadap pemberian na ma wisata Embung Sungai Nanam, 3) kurangnya sarana pra sarana yang ada diwisata, yang diakibatkan keterbatasan dana yangterjadi.
\end{abstract}

Kata kunci: wisata Embung, kendala, pengembangan

\begin{abstract}
Jorong Aie Sanam is a jorong located in Na ga ri Sungai Na nam Gumanti Valley District solok regency. Jorongaie sanamhas abeautifulviewa ndits starategis location surrounded by hills. The tourism potential in Jorongan Aie Sanam is in the form of Nanam River and CambaiBukik. The Nanam RiverEmbung was established in 2017, which was built by PUPR which was then in its management handed over to the community of Aie Sanam. In its management, thecommunity makes Embung a s a tourist attraction. Namu is in management, so far the tour has not been so optimal. This research aims to describe the obstacles experienced by the community in developing the NanamRiverEmbungTourism Attraction in Aie Sanam in the Kecematan Gumanti Valley of Solok Regency.This research uses the theory of structuralfunctionalism of the pa radigm of socialfact rega rding dysfunction put forwa rd by Robert K. Merton. This research includes a type of descriptive research with a qua litative approach. The selection of informants uses purpose sampling with the number of informants 9 people, the type of data used in this study is primary and secondary da ta. The method of collecting data used is non-participant observation and in-depth interview, the data analysis unit used that is the group. The data analysis techniques used are miles and hubeman models. The results of the research show that the constraints of the community in expanding Nana m river Embung tourism in jorong Aie Sanam due to 1) limited funds and misappropriation of funds, 2) lack of community cooperation resulting from the sensitivity of the community, as well as the pros and cons of the community towards the naming of tourism Embung Sungai Nanam,3) the lack of infrastructure facilities that are in the tourism, which is due to the limited funds that occur.
\end{abstract}

Key words: Embung tourism, constraints, development 


\section{PENDAHULUAN}

Wisata menurut UU No.10 Tahun 2009 adalah kegiatan perjalanan yang dilakukan oleh seseorang atau sekelompok orang dengan mengunjungi tempat tertentu untuk tujuan rekreasi, pengembangan pribadi, atau mempelajari keunikan daya tarik wisata yang dikunjungi dalam jangka waktu sementara. Pariwisata merupakan salah satu sektor yang diandalkan oleh pemerintah untuk mendapatkan devisa dan penghasilan. Dalam sektor pariwisata daerah masyarakat sangat berperan penting dalam peningkatannya, dimana sektor pariwisata dapat meningkatkan kualitas dan kuantitas suatu daerah. Perkembangan wisata akan menjadi trend menarik dimasa depan berdasarkan banyak alasan yang rasional, namun potensi yang bagus akan lebih berhasil jika dapat dikembangkan dan dikelola dengan baik. Minimal ada empat unsur yang harus diintegrasikan yakni unsur atraksi atau daya tarik wisata, unsur amenitas atau infrastruktur dan fasilitas pendukung, unsur aksibilitas berupa publik transportasi yang baik, manajemen transportasi yang efisien dan efektif (Utama, 2012)

Dengan adanya perkembangan pariwisata disuatu daerah juga dapat membawa dampak yang positif maupun negatif bagi perkembangan daerah tersebut adapun dampak dari positifnya bisa meningkatkan ekonomi masyarakat, serta dapat memajukan daerah tersebut dan lain-lain sedangkan dari efek negatifnya dapat menimbulkan permasalahan dari masyarakat itu sendiri seperti dari pengelolaan, pengembangan, serta konflik lainnya. Selain itu dalam mengembangkan pariwisata suatu daerah sapta pesona juga sangat dibutuhkan guna meningkatkan pariwisata suatu daerah.

Ada tujuh unsur sapta pesona tersebut yang menjadi sasaran yang perlu diwujudkan dalam upaya meningkatkan pariwisata yaitu aman, tertip, bersih, sejuk, indah, ramah tamah dan kenangan.Aaman disini maksudnya yaitu bebas dari gangguan kejahatan dan lainnya, tertip yaitu dari segi kelakuan, mematuhi budaya antri, bebas dari parkir liar, bersih disini bebas dari sampah dan rumputan liar yang menggangu keindahan wisata, sejuk dapat memberikan kesejukan dan kenyamanan bagi pengunjung, indah dapat memberikan keindahan yang memanjakan pengunjung yang datang, keramah tamahan dapat memberikan kesan yang baik kepda pengunjung yang datang dan memberikan rasa kesopanan dan rasa menghargai terhapap pengunjung maupun masyarakat disekitar, kenangan dapat memberikan kesan yang baik yang dapat diingat pengunjung terhadap pengalaman yang didapat saat berkunjung ke daerah wisata.

Namun tidak semua pariwisata dapat mengembangkan pariwisata daerahnya dengan baik hal ini dapat dilihat dari keadaan wisata itu sendiri, berdasarkan hasil observasi peneliti dilapangan terkait perkembangan wisata daerah di Aie Sanam pada wisata Embung Sungai Nanam yang terletak di Kecamatan Lembah Gumanti, Kabupaten Solok, yang mana jika dilihat daerah ini memiliki potensi yang bagus untuk segi pariwisata, namun hal ini tidak dimanfaat dengan bagitu baik oleh masyarakat itu sendiri. Dari observasi yang dilakukan peneliti di daerah tersebut dimana wisata tersebut didirikan pada tahun 2017 yang pengelolaannya semua diserahkan kepada masyarakat, namun dari tahun ketahun wisata tersebut mengalami kemunduran baik dari pengelolaanya maupun dari jumlah pengunjung yang datang. Dari segipengelolaan sekarang wisata ini tidak ada yang mengelola serta wisata Embung ini dibiarkan terbengkalai begitu saja, dari segi pengunjung berdasarkan data di lapangan jumlah pengunjung dari tahun ketahun wisata Embung ini mengalami penurunan. Dilihat pada tahun 2017 yaitu 600 orang, pada tahun 2018 mengalami penurunan yaitu 420 orang, dan pada tahun 2019 mengalami penurunan yang sangat darastis sebanyak 250 orang. 
Tabel 1.1 Jumlah Pengunjung tahun 2017-2019

\begin{tabular}{|lll|}
\hline NO & Tahun & \multicolumn{1}{c|}{ Jumlah Pengunjung } \\
\hline 1. & 2017 & 600 orang \\
2. & 2018 & 420 orang \\
3. & 2019 & 250 orang \\
\hline
\end{tabular}

Sumber: Jorong Aie Sa nam (2019)

Dari data jumlah pengunjung diatas terlihat bahwa wisata Embung Sungai Nanam mengalami penurunan. Hal ini disebabkan karena kurangnya kontribusi masyarakat dalam mengembangkannya. Selain itu dari segi sapta pesona wisata Embung Sungai Nanam tidak terjaga lagi, hal ini disebabkan karena wisata ini tidak lagi di urus baik dari pengelolaannya maupun perkembangannya.

Permasalahan yang menyebabkan wisata ini menjadi terbangkalai dimunculkan akibat pemberian nama yang ditentang oleh sebagian masyarakat, serta adanya perselisihan antara masyarakat sekitar. Alasan peneliti menjadikan permasalahan ini sebagai penelitian direnakan peneliti tertarik untuk mengungkap permasalahan yang menyebabkan kenapa wisata ini tidak dikembangkan dengan baik padahal dari segi ekonomis, keindahan serta potensi perkembangan wisata dapat meningkatkan pendapatan daerah maupun masyarakat.

\section{METODE PENELITIAN}

Penelitian ini menggunakan teori fungsionalisme struktural yang di kemukakan Robert. K Merton, pendekatan yang digunakan dalam penelitian ini adalah pendekatan kualitatif.

Adapun tipe penelitian ini menggunakan tipe penelitian deskriptif, yang mana dalam penelitian yang digunakan untuk memusatkan perhatian pada permasalahan penelitian pada saat melakukan penelitian. Untuk pendekatan kualitatif dapat menggambarkan keadaan yang terjadi terhadap pengembangan wisata Embung Sungai Nanam. Hal ini dapat melihat apa yang menjadi kendala masyarakat dalam mengembangkan wisata Embung tersebut.

Informan penelitian adalah orang yang memberikan informasi baik tentang dirinya maupun orang lain atau suatu kejadian kepada peneliti, yang tidak mereka pahami sebagai objek, sebagai orang yang memberikan respon terhadap suatu hal yang berada diluar diri mereka melainkan subjek (Afrizal, 2014). Dalam penelitian ini, peneliti melakukan wawancara dengan 9 informan yang telah memenuhi kritera informan yang telah ditentukan, yaitu mulai dari jorong Aie Sanam, ketua pengurus wisata Embung, pedagang masyarakat serta pengunjung yang datang ke wisata tersebut.

Data dalam penelitian ini mengunakan data primer dan sekunder. Data primer merupakan data yang diperoleh peneliti dari sumber asli (langsung dari informan) yang memiliki informasi atau data tersebut (Muhammad, 2009). Adapun data primer yang diperoleh peneliti dalam penelitian di Aie Sanam yaitu wawancara dengan jorong Aie Sanam, ketua pengurus wisata Embung, pedagang, masyarakat serta pengunjung wisata Embung tersebut. Adapun data sekunder yang diperoleh peneliti berupa data- data perangkat nagari, seperti profil nagari dari jumlah penduduk, data potensi nagari Sungai Nanam, data luas wilayah nagari menurut penggunaanya. Teknik pengumpulan data yang digunakan dalam penelitian yaitu observasi, wawancara, dan studi dokumen. Observasi yang digunakan dalam penelitian observasi nonpartisipan, dimana peneliti tidak terlibat lansung dilapangan namun hanya sebagai pengamat. Diamana selama observasi maupun selama penelitia peneliti mengamati aktifitas masyarakat di wisata tersebut, dan respon masyarakat terhadap wisata tersebut. 
Wawancara yang digunakan yaitu wawancara mendalam, dimana selama penelitian maupun observasi, peneliti melakukan wawancara dengan perangkat nagari, jorong serta masyarakat terkait dengan permasalahan yang terjadi, serta kenapa mesyarakat tidak melakukan pengembangan wisata dengan baik. Selain itu studi dokumen dalam penelitian ini berupa lampiran foto wisata, buku untuk referensi, jurnal dan lain-lain.

Unit analisis dalam penelitian ini adalah unit analisis kelompok, seperti masyarakat, anggota PKK, serta perangkat nagari lainnya. dalam hal ini peneliti ingin melihat apa yang menjadi kendala masyarakat, ketua pemuda dan jorong aie sanam dalam mengembangkan pariwisata Embung Sungai Nanam. Dengan menggunakan analisis data dari Milles dan Huberman yang harus digunakan dalam menganalisis data kualitatif seperti masalah reduksi data, penyajian data, dan penarikan kesimpulan menjadi gambaran keberhasilan secara berurutan sebagai rangkaian kegiatan analisis yang saling menyusul (Miles dan Huberman, 1992: 20). Lokasi penelitian Penelitian ini dilakukan di Daerah Aie Sanam Kecamatan Lembah Gumanti Kabupaten Solok. Yang dilakukan pada bulan Juli sampai Agustus.

\section{HASIL DAN PEMBAHASAN}

\subsection{Hasil}

Pada bab ini peneliti akan mendeskripsikan hasil penelitian terkait bagaimana kendala masyarakat dalam mengembangkan Objek Wisata Embung Sungai Nanam Di Jorong Aie Sanam Kecamatan Lembah Gumanti Kabupaten Solok. Data yang diperoleh melalui observasi, wawancara dan studi dokumen, hasil penelitian. Adapun pengembangan yang dilakukan masyarakat dalam mengembangkan objek wisata Embung Sungai Nanam ini sebagai berikut.

1. Pengelolaan objek wisata Embung Sungai Nanam

Embung Sungai Nanam berdiri sejak tahun 2017, yang dibangun oleh PUPR yang kemudian dalam pengelolaannya diserahkan kepada masyarakat Aie Sanam. Dalam pengelolaannya ini masyarakat menjadikan Embung sebagai objek wisata, masyarakat diminta untuk mebenahi dan mengembangkan wisata. Dalam pengelolaannya masyarat melakukan yaitu dari segi

a. Pengelolaan sarana dan prasarana

Dari pengelolaan sarana prasana msyarakat melakukan pengembangan dari tahun 2017, dimana masyraakat bekerjasama dalam pembenahan wisata seperti pembenahan taman pengisian benih ikan. Namun dari tahun ketahun pengelolaan ini tidak berjalan dengan baik, dimana dulunya masyarakat saling bekerjasama dengan anggota PKK nagari dalam pembenahan tersebut untuk mengmabngkan keindahan wisata, tetapi hal ini tidak berjalan dengan baik. Ini terjad akibat perbedaan pendapat dari masyarakat maupun pengurus. Dari hasil observasi dilapangan ditemui banyak masyarakat acuh tak acuh dan tidak begitu memperhatikan keadaan wisata, dilihat dari sarana prasana yang rusak seperti, tamana yang ditumbuhi rerumputan liar, sampah berserakan dimana-mana, serta pot taman yang rusak. Selain itu benih ikan larangan yang dilepaskan di dalam Embung tersebut sudah banyak dicuri orang. Dari hasil wawancara dengan masyarakat dan bapak jorong, dalam pengelolaan wisata ini sekarang sudah tidak berjalan dengan baik, hal ini juga terlihat dari uang masuk dan keluar untuk wista tidak ada rincian yang jelas.

Jika dikaitkan dengan teori fungsonlisme struktural yang dikemukakan oleh Robert K. Merton terkait disfungsi dapat dilihat bahwa tidak berjalanya fungsi didalam msyarakat baik dari jorang maupun pengurus wisata hal ini diakibatkan karena perbedaan pendapat yang terjadi dalam masyarakat terhapa perkembangan yang dilakukan untuk wisata Embung Sungai Nanam.

b. Pengelolaan keamanan

Dalam pengelolaan kemanan sangat diperlukan untuk menunjang pengembangan pariwisata, dimana dengan adanya kemanan membuat wisatawan akan menjadi nyaman 
dalam berkunjung serta tidak khawatir akan keselamatan harta bendanya.

Dari hasil observasi dilapangan untuk segi pengelolaan keamanan, wisata ini tidak berkembang dengan baik dimana sudah didrikan pos keamanan, tetapi masyarakat tidak memanfaatkannya dengan baik selain itu sekarang wisata ini tidak mengalami perkembangan dari tahun ketahun juga menyebabkan keamanan tidak berjalan dengan baik. Dari hasil wawancara yang dilakukan dilapangan, bahwa keamanan untuk wisata ini tidak lagi ada hal ini diakibatkan wisata tidak berjalan baik, gaji untuk pegawai keamanan tidak dikeluarkan, serta pos keamana juga sudah banyak yang rusak bahkan tidak bisa digunakan sama sekali.

Terkait dengan teori yang digunakan dalam permasalahan ini dapat dilihat fungsifungsi yang ada dalam maysrakat tidak digunakan dengan baik, serta menyebabkan terjadinya disfungsi yang menyebabkan wisata menjadi tidak berkembang, serta kurang terbukanya pengeuru dengan perangkat nagari seperti jorang dan masyrakat.

c. Pengelolaan kebersihan

Dalam pengelolaan suatu wisata kebersihan sangat diperlukan guna kemajuan wisata itu sendiri, dimana dengan kebersihan yang terjaga akan membuat pengunjung nyaman untuk berkunjung. Selan itu kebersihan suatau wisata akan membawa dampak yang baik bagi wisata itu sendiri. Oleh sebab itu dalam meningkatkan kebersihan wisata, tempat sampah sangat diperlukan.

Berdasarkan hasil observasi yang dilakukan di wisata tersebut semua kebersihan wisata tidak terjaga dengan baik, sebagaimana halnya dengan wisata Embung Sungai Nanam, sebelumnya dalam pengelolaan wisata Embung ini sekali seminggu masyarakat melakukan goro bersama, untuk membersihkan wisata, seperti membersihkan rumput yang sudah tinggi disekitar wisata, membersihkan taman-taman yang ada, serta mebersihkan sampah-sampah yang berserakan di pintu masuk wisata dan di dalam selokan. Namun sekarang, dalam segi kebersihan wisata tersebut kurang terjaga dengan baik, diliat dari selokan, taman, dan didalam Embung serta disekitar pintu masuk banyak sampah berserakan, membuat selokan jadi tersumbat, selain itu rerumputan liar sudah makin banyak tumbuh disekitar Embung. Dari wawancara dengan ketua pengurus wisata Embung Sungai Nanam dari segi pengelolaan kebersihan sekarang wisata ini tidak lagi terjaga, dari pendapat masyarakat mereka ingin memperbaiki wisata ini namun mereka tidak berminat lagi karena akan menimbulkan masalah lagi, yang mana dalam pengelolaan wisat sudah banyak terjadi masalah dalam masyarakat.

Dari permasalahan ini pengunjung yang biasanya banyak berkunjung namun sekarang tidak lagi, sehingga menyebabkan perekonomian masyarakat jadi berkurang, dikarenakan tidak beberapa orang yang datang berkunjung ke wisata tersebut.

2. Program pengembangan objek wisata Embung Sungai Nanam

Dalam mengembangkan pariwisata suatu daerah program-program untuk pengembangan wisata harus jelas dan bernar tertata dengan baik guna perkembangan wisata menjadi menarik dan banyak diminati wisatawan. Namun tidak semua program dapat terjalan dengan baik, terdapat berbagai hambatan yang terjadi dalam program pengembanganya. Selain itu program yang dijalankan juganharus tepat sasaran.

Salah satunya program yang dijalan kan oleh masyarakat wisata Embung Sungai Nanam. Dalam mengembangkan wisata Embung masyarakat dan beberapa perangkat jorong lainnya melakukan beberapa program untuk membenahi wisata Embung yang mana program yang telah dilakukan berupa pembenahan taman yang berada di Embung tersebut, membuat pos penjagaan wisata, pengeisian benih ikan larangan yang dipanen enam bulan sekali.

Adapun program yang dialakukan masyarakat dalam mengembangkan objek wisata adalah sebagai berikut.

1. Promosi 
Promosi dalam dunia pariwisata sangan diperlukan, sehingga dapat mendatangkan keuntungan untuk pariwisata itu sendiri tidak hanya itu untuk melakukan suatu promosi harus didukung dengan proses perbaikan dan pengembangan, dalam melakukan promosi tidak hanya masyarakat maupun pemerintah, kalangan anak muda sekarang juga harus giat dalam meningkatakan promosi wisata suatu daerah guna meningkatkan daya tarik pengunjung yang datang berwisata.

Namun dapat dilihat tidak semua perpromosian wisata dapat berkembang dengan baik, ditambah lagi kurangnya pemahaman masyarakat akan promosi wisata yang menyebabkan terkendalanya suatu program dalam mengembangkan pariwisata. Salah satunya di daera Aie Sanam. Yang mana terdapat salah satu wisata Embung Sungai Nanam yang berdiri pada tahun 2017 lalu.

Sementara itu dengan perpromosian wisata yang dilakukan masyarakat dan pengurus terhadap wisata Embung Sungai Nanam dapat meningkatkan perkembangan wisata. Namun hal ini tidak terjadi pada wisata Embung Sungai Nanam yang mana walaupun masyarakat maupun pengurus melakukan promosi dengan baik, wisata ini tidak mengalami perkembangan dari tahun ketahun. Hal ini dapat dilihat dari promosi yang dilakukan hanya melaui facebook, ), grup aspirasi masyarakat minang, berita nagari, like padang, info minang, dan melalui web http://www.suhanews.com promosi wisata yang dilakukan ditujukan kepada para masyarakat daerah maupun mancan negara.

Selain promosi masyarakat dalam mengembangkan wisata masyarakat juga melakukan sosialisasi ke masyarakat sekitar dengan mengarahkan masyarakat untuk mempelajari bagaimana mengembangkan wisata dengan baik serta memotivasi masyarakat untuk lebih giat dalam mengembangkan pariwisata.

Walaupun sudah di adakan sosialisasi, pengembangan terhadap wisata tidak berjalan dengan baik, yang di akibatkan kurangnya pemahaman masyarakat akan sadar wisata ditambah lagi dengan permasalahan-permasalahan yang terjadi pada wisata tersebut.

2. Pencarian dana untuk pengembangan wisata.

Untuk melaksanakan pengembangan kegiatan pariwisata, masyarakat maupun pengurus dapat menganggarkan dana untuk pengembangan wisatanya, yang mana setiap daerah pasti memiliki keunggulan masing-masing, seperti halnya jorong Aie Sanam yang memiliki potensi wisata Embung Sungai Nanam. Sehingga dengan adanya wisata ini dapat memajukan masyarakat sadar wisata. Dalam melakukan pengembangan suatu wisata, namun dana yang ada tidak selalu mencukupi untuk pengembangan yang dilakukan. Sehingga membuat masyarakat harus memikirkan berbagai cara untuk mendapatkan dana demi pengembangan wisata. Hal yang dilakukan masyarakat dalam program ini yaitu dengan melakukan pembuatan proposal yang diajukan kepada para anggota DPRD yang ada didaerah tersebut, tidak hanya itu masyarakat juga meminta sumbangan ke masyarakat. Namum dari program yang dijalan kan belum begitu optimal dimana masih terdapat berbagai kendala-kendala yang terjadi.

3. Kendala dalam pengembangan objek wisata Embung Sungai Nanam

Dalam mengembangkan wisata suatu daerah tidak selalu berjalan dengan baik dimana masih terdapat kendala yang ditemui. Hal ini dapat dilihat dari wisata Embung Sungai Nanam dimana terdapat berbagai kendala dalam pengembangan wisatanya.

1. Keterbatasan dana dan penyelewengan dana

2. Kurangnya kerjasama masyarakat dalam mengembangkan wisata Embung Sungai Nanam yang disebabkan sensitifitas dalam masyarakat.

3. Kurangnya sarana prasarana yang memadai.

Dari permasalahan yang terjadi, sekarang perangkat nagari maupun jorong meminta masayarakat untuk bekerjasama untuk memperbaiki dan biaya yang sudah diselewengkan, akan diproses dan musyawarahkan secara bersama, namun jika masaih ada masayarakat yang tidak terima 
akan hal tersebut nantinya pada saat wisata sudah bisa dan terawat lagi, dan sudah seperti semula, jika mereka akan masuk kewisata tersebut akan membayar, baik itu parkir ataupu tempat berjualan.

Namu jika wisata ini juga tidak di perbaiki, maka pihak nagari akan menyerahkan kembali kepada PEMDA, untuk mengelola wisata ini kembali, karena biaya yang sudah dikeluarkan untuk membangun tempat ini sangat besar, dan bagi masyarakat yang berada di sekitar wisata akan membayar jika mereka ingin berkunjung ke wisata tersebut.

\subsection{Pembahasan}

Berdasarkan hasil penelitian diatas, terkait kendala masyarakat dalam mengembangkan objek wisata Embung Sungai Nanam dapat dikaitkan dengan teori fungsionalisme struktura dari pradigma fakta sosial tentang disfungsional yang dikemukaakn oleh Robert K. Merton. Bahwa dalam teori ini berbicara terkait analisis struktural yang memusatkan perhatian pada kelompok sosial, organisasi, masyarakat dan kebudayaan. Teori struktural menurut Robert K. Merton adalah menekankan kepada keteraturan dan mengabaikan konflik dan perubahan-perubahan dalam masyarakat. Konsep utamanya adalah fungsi, disfungsi, fungsi laten dan fungsi manifes dan keseimbangan (Ritzer, 2007).

Menurut Merton fungsional dibagi menjadi dua yaitu fungsi nyata dan fungsi tersembunyi. Berdasarkan penjelasan terkait dengan kendala yang dialami masyarakat dalam mengembangkan objek wisata Embung Sungai Nanam, dimana terjadinya disfungsi dalam anggota masyarakat untuk mengembangkan objek wisata Embung Sungai Nanam. Hal ini disebabkan kurangnya keterbukaan pengurus wisata dengan masyarakat dan perangkat jorong, sehingga menyebabkan wisata tidak dapat berkembang dengan baik, ditambah lagi adanya pro dan kontra antara masyarakat dalam perdebatan nama wisata, yang menyebabkan masyarakat saling tidak peduli.

Sehingga jika dilihat, tidak berjalannya fungsi-fungsi didalam masyarakat, yang mengakibatkan terjadinya kendala-kendala dalam mengembangkan objek wisata Embung Sungai Nanam, seperti keterbatasan dana dan penyelewengan dana, kurangnya kerjasama masyarakat dalam mengembangkan wisata Embung Sungai Nanam yang disebakan oleh sensitifitas dalam masyarakat serta kurangnya sarana prasarana yang ada. Hal ini mengakibatkan tidak berkembangnya pariwisata Embung Sungai Nanam dengan baik dari tahun ke tahun.

\section{KESIMPULAN}

Beradasarkan hasil penelitian terkait kendala masyarakat dalam mengembangkan objek wisata Embung Sungai Nanam di jorong Aie Sanam Kecamatan Lembah Gumanti Kabupaten Solok dapat disimpulkan bahwa wisata Embung Sungai Nanam ini dari tahun ketahun tidak mengalami perkembangan, dilihat dari prasarana yang ada, keadaan wisata, serta kemajuan wisata itu sendiri tidak berkembang dengan baik. Hal ini disebabkan karena terdapat beberapa kendala yang menyebabkan wisata ini tidak berkembang dengan baik, seperti keterbatasan dana dan penyelewengan dana, yang mana dari dana yang ada anggaran untuk pengembanga belum cukup ditambah dana yang sudah terkumpul dari insert pemancingan ikan tidak lagi ada dikerenakan, adanya penyelewengan yang dilakukan sebagian pengurus, kurangnya kerjasama dalam masyarakat, kurangnya sarana prasarana yang memadai.

\section{Ucapan Terima kasih}

Ucapan terimakasih pertama yakni kepada masyarakat sekitar objekwisata Embung Sungai Nanam Di Jorong Aie Sanam Kecamatan Lembah Gumanti Kabupaten Solok yang sudah menjadi informan dan membantu dalam memberikan data penelitian ini. Selanjutnya kepada pemerintah daerah khususnya Jorong Aie Sanam Kecamatan Lembah Gumanti KabupatenSolok. Serta ucapatan terima kasih juga kami sampaikan kepada Dr Putu Sucita Yanthy, SS.M.Par selaku Editor in Chief dan dan tim editorial lainnya pada jurnal Kepariwisataan dan Hospitalitas, Fakultas Pariwisata, Universitas Udayana, Bali, Indonesia 


\section{DAFTAR PUSTAKA}

Afrizal, M. A. (2014). Metode Penelitian Kualitatif . (PT RAJA GR).

Bakaruddin. (2009a). Perkembangan Dan Permasalahan Kepariwisataan (UNP PRESS).

J, George Ritzer dan Goodman Douglas. (2011). Teori-Teori Sosiologi Modern (Kencana Pr). Lexy M. j. (2013). Metode Penelitian Kualitatif (Remaja Ros).

Miles Matthew B, Dan Huberman, A Michael. (1992). Analisis Data Kualitatif (UI Press).

Muhammad, I. (2009). Metode Penelitian Ilmu Sosial (Erlangga).

Nazir. (2009). Metodologi Penelitian (GAHALIA IN).

Pitana I. G. (2009). Pengantar Ilmu Pariwisata.

Prof. Dr. Lufri. (2007). Penelitian Kualitatif.

Ritzer G. (2007). Sosiologi Ilmu Pengetahuan Berparadigma Ganda (PT. Raja Gr).

Sugiyono. (2010). Metode Penelitian Kuantitatif, Kualitatif Dan R\&D (Alfabeta).

Suharsimi A. (2010). Prosedur Penelitian Suatu Pendekatan Praktik. (Rineka Cipta).

Suwantoro. (2004). Dasar-Dasar Pariwisata (Andi).

Oktaviani. 2010. Peran Pemuda Dalam Pengelolaan Pariwisata Pantai Aia Bangih Kecamatan Sungai Beremas Kabupaten Pasaman Barat. Skripsi. Padang: STKIP PGRI Sumatera Barat.

Paradilla. 2013. Kontribusi Sektor Pariwisata Terhadap Pendapatan Asli Daerah Kota Sawahlunto Dari Tahun 2010-2015. Skripsi. Padang: STKIP PGRI Sumatera Barat.

Sariabbangan. 2013. Kontribusi Masyarakat Lokal Pengembangan Pariwisata Kepulauan Mentawai. Skripsi. Padang: STKIP PGRI Sumatera Barat.

Undang-Undang Republik Indonesia No 10 Tahun 2009 Tentang Kepariwisataan.

Gede Sunarjaya, dkk. (2018). Kendala Pengembangan Desa Wisata Mungu Kecamatan Mengwi, Bandung. Jurnal Jumpa 4(2): 216-217

Heri, Larasati. 2011. Strategi Pengembangan Pariwisata Kabupaten Pati. Jurnal Universitas Diponegoro IdaZahara Adibah. (2017). Struktural Fungsional Robert K.Merton: Aplikasinya Dalam Keluarga.Jurnal Inspirasi 1(2): 175-178

Prakoso, E. (2012). Perkembangan desa wisata kembang arum dan dampaknya terhadap kondisi sosial ekonomi masyarakat donokerto kecamatan turi. volume2, 1-10.

Rahmayanti Dwi Yunita. (2015). Dampak Keberadaan Objek Wisata Waduk Sermo Terhadap Perubahan Sosial Ekonomi Masyarakat Di Saremo, Kulon Progo Daerah Istimewa Yogyakarta. Jurnal pendidikan Sosiologi: 1-8. Tapatfeto (2018). Journal of Management. 6, 19. 